\title{
Alternative Education and Self-Regulated learning: Multiple Case Study
}

\author{
Ana García Díaz \\ Universidad Complutense de Madrid, Spain
}

\begin{abstract}
Are traditional schools encouraging children to become self-sufficient learners? Are they taking into account pupils' real needs? What are those needs? The work in progress is trying to answer these questions, with a comparison of the development of pupils' self-regulation skills in democratic and traditional primary schools. This research is a multiple case study to discover how different types of schooling develop self-regulated learning skills and how this is achieved. Specifically, what are the differences that lead one type of school to developing these skills more than others.
\end{abstract}

\section{Introduction}

In the Eurostat Report on School dropout from 2013 [1, 2] Spain ranks among the lowest countries with $23.5 \%$ of teenagers age sixteen abandoning school before finishing secondary school.

Some of the reasons for this could be related to the lack of flexibility in the content-centered curriculum. This content is organised in subjects and in rigid schedules. For the teachers, this means they do not have time to consider children's needs since they have to focus on the yearly content goals they have to achieve.

This figure could explain why we have been witnessing, for the last four years, an increase in the number of alternative schools in Spain. Most of these schools have been created by groups of parents who do not agree with the traditional educational system because they feel it does not correspond to the needs and requirements of children in the 21 st century. There are no official numbers yet, but the main list of alternative education projects in Spain is growing fast and every year we can find new schools or traditional schools that have decided to change their pedagogical methods and outlooks on teaching. (http://ludus.org.es/) However, in Spain, most of these schools are not legally recognized by the government and so some become private schools.

Having no legal status or the possibility of getting it from the Spanish government, means that some schools look for recognition in other countries like the USA or Panama, thus becoming international schools. This means, even when they are located in Spain, they are governed by the rules of another country.
There are even some schools that have no legal recognition at all. Legally they do not exist as schools but as learning associations or families' organizations. Thus, children will not receive any certification at the end of their studies. Some of these educational projects encourage children and families to apply for online education in countries where this type of schooling is legally recognised.

In this kind of school, families expect their children to be given an alternative to the traditional method of teaching and learning. But education is not something that just happens in schools, the family is also an important institution for children's learning which is why some parents decide to homeschool their children when they disagree with the educational methods and approaches in the current educational system.

\section{Literature Review}

In Spain, alternative schools are not just a general change in the teaching methods, but a change in the way we understand the educational institution, principles and philosophy. The goal of these schools is to take into account children's natural development processes and to adapt teaching strategies, materials, even the classrooms to their needs, which means learning will become something natural, allowing pupils to learn in a self-regulated way and promote meaningful learning.

In 1876 a school in Madrid called Institución Libre de Enseñanza (ILE) was created in order to promote pedagogical reform. Its purpose was to encourage pupils to become critical, active, free and independent citizens. In order to achieve these goals they banished traditional lessons and instead learning was through a research process [4]. Molero [4] drew up guidelines for ILE's teachers to strengthen students' passion and motivation for learning. The aim was to turn lessons into fluent dialogues between teachers and pupils.

In a similar way, alternative schools are focused on developing the essence of being human (such as emotions, human/ moral/ critical thinking, communication skills, self-regulated learning), freedom and independence. This is why creative education is a vitally important part of the teaching in these schools. The teachers see art, philosophy, music, and writing as a way for children to express 
and understand themselves. This way of learning can be used (and is used) to develop the knowledge of traditional subjects like language, mathematics and science. This teaching ethos is based on children's central interests, so pupils are motivated to learn due to their interest in the subject, and teachers, in return, use their students' passion for these topics to develop other skills.

Illustrious philosophers and pedagogues such as Montessori [5], [6], Pestalozzi [7], Neill [8], [9] and Rosseau [10], [11] have asserted that the child has an inner curiosity and passion for learning as well as an inner need to learn. Thus, the role of school is to provide them with resources to satisfy those needs and also keep their passion and curiosity undiminished.

The learning process can be a creative journey where children build their own knowledge in accordance with their own needs.

In general terms, creativity means the "ability to produce something new" [12]. Thus, humans and, especially, children are creative beings. It is important to encourage children to feel confident with their own creative skills and to develop initiative. At the same time, becoming a selfregulated learner is directly connected with developing self-awareness, the ability to regulate their own emotions and to manage their own time.

Several authors [13], [14] define self-regulation as a "self-managing process where students can materialize their mental activity in activities and skills required to operate in diverse areas". To understand self-regulation it becomes vital to be aware of the elements that are part of it. Metacognition, cognition coupled with motivation, conduct and context are understood as the ingredients in order to become a successful independent learner [15], [16], [17].

It is essential to reflect on what pupils will need to become successful in adult life. Based on one dictionary definition [12], success can be defined as the "achieving of the results wanted or hoped for". Taking this definition into account, the definition of success used in this paper is:

The satisfactory achievement of personal, professional, social and life goals. Success is the natural consequence of the personal effort to reach a goal of any kind, generating a feeling of happiness and satisfaction.

Thus, success is the result of pursuing happiness and personal satisfaction. From this we can conclude that children do not need only knowledge-based learning to be successful in their future adult lives, they will need creativity, personal and emotional skills. It can be argued that the core of alternative education is to educate children towards developing self-consciousness, creativity, initiative, personal and emotional skills and critical thinking, as well as to encourage them to become aware of their responsibilities as citizens in a democratic society.

To achieve these goals, children must be respected, loved and appreciated. This implies that we must respect their individual process of development as well as making them feel that everything they have to say is valuable [5], [6], [7], [8], [9], [10]. [11], [17], [18], [19], [20], [21], [22]. At the same time, respect implies we understand how important it is for a child to play. Playing is a natural component of children's life and the instinctive way they learn [25] Play allows children to notice learning as something fun that they want to keep doing. Likewise, curiosity, research skills and creativity will be strengthening their learning. Knowledge that is acquired by research based on the person's interests is meaningful for her/him and becomes easier to remember and to link with real life since it is connected with previous learning [23].

In Democratic Schools the adult plays an important role in pupils' learning processes. (Adult rather than teacher.) They become a guide or a companion instead of an authority. The adult should be there to provide resources to fulfil children's needs, encouraging them to reflect about everything they read or experience, as well as being a mediator when conflicts arise. The adult needs to set an example for children of respectful communication, active listening and peaceful conflict resolution [5], [6], [7], [8], [9], [10], [11], [17], [18], [19], [20], [21], [22].

\section{Research Rationale}

The work in progress is a multiple case study where two schooling types are being compared, (alternative and traditional). The design is not experimental, specifically Ex Post Facto, studying the variables in their natural context without trying to control them. In the comparison of the two schooling types: alternative and traditional [26]. The purpose is to create a complete and detailed overview of the characteristics of both types of school and study the results produced by the primary school pupils.

The research will explore relationships between the teaching methods used in classrooms and the level of self-regulation that pupils show in the research test.

This is a concurrent mixed method study (qualitative as well as quantitative) [26].

Therefore, two different data-collection instruments will be used:

- Quantitative data: Test to evaluate the state of skills

- Qualitative data: Observation notes and semistructured interview with teachers.

Regarding the questionnaire, the researcher could not find tools to evaluate the level of self-regulated skills in Primary School children. For this reason, a 
questionnaire was being created to evaluate cognitive and metacognitive process involved in selfregulation such motivation, critical thinking, time management and creativity. This instrument was based on others already created [27], [28], [29].

The data has been collected, from three schools: a Democratic School in Spain; an Active School in Scotland and a Traditional Catholic School in Spain.

SPSS is being used to analyse the quantitative data [30]. In respect of the qualitative data, it is being analysed on the case-oriented understanding [31]. Interviews and observation notes are being analysed at the moment.

\section{Initial Findings}

As the analysis is ongoing, initial findings are presenting here which related to the qualitative data. Firstly, the information obtained through the observation notes are going to be presented, analysing each specific case in terms of classroom structure, daily routine, discipline and their relationship with surroundings.

Secondly, a comparison of interview responses will show the differences between the school's philosophers.

In terms of the Traditional Catholic School, the structure of the classrooms in Primary School gives us information about the teaching method that it is being used which, in this case, is rote learning. That means, it is based on memorization and repetition as well as on one-way communication between pupils and teachers.

All desks are in line facing the blackboard where the teacher is explaining the content. Children are not allowed to speak unless they have a question and the teacher gives them permission to talk. They have to be sitting down in their places until break time which happens twice during the morning. Pupils are separated by ages in different classrooms.

Regarding the daily routine, children have a different subject every fifty minutes. It usually starts with a lecture about the content followed by the completion of exercises proposed by the teacher. It is mandatory to participate in every activity.

With respect to discipline, teachers supervise compliance with rigid rules that the school is governed by. If pupils do not comply they will be threatened with going to the principal's office, the teacher speaking with their parents to be punished at home or being punished at school by not having breaks.

The active school in Scotland and the Democratic school in Spain have quite a few things in common. Both classrooms are prepared for active learning, enabling free access to learning resources as well as letting pupils walk freely around the classroom to get the information they need to do their research. Both schools provide a relaxed and respectful environment since children's own pace is respected.

Returning to discipline, neither of these schools use punishment as a way to teach pupils self-control. Instead, children are encouraged to solve their problems in empathetic conversations moderated by an adult, discussing their differences, thus becoming aware of the emotions involved in that situation.

Regarding the daily routine, the Democratic School as well as the Active one, start every morning with a meeting for the pupils to share how they are feeling or discuss anything they feel worried about. Later they will do what they call concentration work, which means, work on content such as maths, languages or science. In the afternoon take place workshops, children can choose to attend, stay in the room reading a book or play outside in the garden.

Regardless of the similarities between these two schools, there are also organisation and methodological differences.

In the Active School in Scotland pupils are separated by levels in multi-composite classrooms formed of P1 to P3 (4 to7 years old) and P4 to P7 (7 to 12 years old). There are two classrooms in each level, one that teaches only in English and the other in Gaelic. In terms of teaching methods, this school works by projects, that implies everybody works on the same topics during the morning, but having different tasks to complete the project. It is a cooperative work.

The Democratic School in Spain does not separate children in classrooms or levels; all primary school pupils work together in the same spaces. The aim is to create natural cooperative relationships between pupils, where they help each other in their learning process. Primary school pupils are able to use three different spaces during morning time: the Science and Math's room, the Technology room, the Language and Reading room. They can choose what they want to work on and change whenever they want to. They are encouraged to organise their own time and their own knowledge becoming main actors in their learning process.

Both schools are located in rural areas, thus it is a priority to teach respect and love for the environment. The forest is a second classroom that provides pupils with resources for their research as well as letting them get to understand the context that surrounds them, learning about topics such as flora and fauna.

In the same way, in the two schools children are encouraged to get involved in the improvement of school performance. In Scotland, a wall called "Feedbook" is provided for the pupils to stick every suggestion or concern they have. In Spain, children are encouraged to share their improvement proposals in the meetings that take place every day in both the morning and afternoon. Furthermore, in the Democratic School pupils created the school rules in 
collaboration with teachers and parents, most of them focused on creating a respectful social environment rather than on curriculum issues.

With respect to the legal status of the three schools, the Catholic school is private under the authority of a religious order, the Active School is a state school and the Democratic one is private, created by families and teachers as an alternative to traditional schools. The last one is one of the few such schools recognised by the Spanish government. Interviews were conducted to help understand the ethos of each school through teachers' perceptions.

In response to the question "tell me four reasons that makes it difficult for you to carry out your tasks as a teacher" all of the teachers in the democratic and active school included budget and time in their answers. By contrast, in the traditional school they answered "children's special needs, demotivated pupils and natural differences between them and unsatisfactory academic performance in terms on bad results in tests".

As far as assessment is concerned, all the schools are different. The traditional school evaluates children by tests, classroom work and homework. In contrast, the democratic school does not evaluate children in a quantitative sense; they write termly reports to families describing children's development, pupils' main interests as well as giving answers to parents' concerns.

In respect of the active school, they assess pupils in many ways such observation, peer and individual assessment, child's own personal assessments and target setting, pupils blogs, classroom discussions, reading group and online evaluation through websites like Sumdog or Khanacademy. The result is a report of the development of the child according to the Scottish Curriculum of Excellence curriculum areas.

\section{Conclusion}

This research is based on the following hypothesis: by developing skills connected with "learning to learn" or self-sufficient learning, schools can enable the development of abilities linked to creativity, entrepreneurial, personal and social skills.

Everyone learns at a different pace and has their own way of learning: self-regulated learning gives children the independence needed to learn following their individual way and timing. This means the individual child will need a deep self-awareness to help them understand themselves and to strengthen their own personal virtues.

Educating children in self-consciousness can provide tools for learning in an independent way while improving their social skills. It is hoped that if we can understand ourselves we will be able to understand others more easily.
There is limited research around self-regulated learning, as it is an underexplored area. The existing research barely speaks about how to develop these skills in primary schools. Most research has centred on e-Learning or adult education. This research should enhance our understanding of the development of self-regulated learning skills in primary school pupils in different learning environments.

Democratic schools in Spain are struggling to regularise their legal status since the existing legislation is focused on content. As a result, my findings may raise awareness of the need to have more educational choices as part of our rights in a democratic society.

It can be seen that one of the main differences between these types of schooling is classroom organisation. Thus, organisation gives us leads about how the classroom work will be like. In this case, three different teaching methods have been compared. One where the classroom is completely controlled by the teacher who uses a discipline method that works through fear, in line with the way they work; one where children create learning in an active way but still guided by the teacher; and the last one where children create their own learning alongside adults. The last two, despite their philosophical differences when managing the classroom, encourage children to solve their problems through communication.

A question may be made at this point; do we trust children's capacities? What is the message we are sending them when we try to control them? That they are worthy, valuable and they have lots of gifts to share with the world or that they are not good enough to do things by themselves?

Connecting methodology with self-regulated learning, it seems that the two last schools encourage children to achieve self-regulation, not just learningwise but emotionally too, providing them with an environment to become critical thinkers; while the first one is educating children to become obedient, and not face their emotions.

Communication is another distinguishing feature between the teaching methods, in the present comparison two different communication styles can be observed: one open and flexible based on questions and another one more authoritarian.

By opting for open communication allows pupils to think by themselves, speak for themselves and feel that what they have to say is valuable. This would build up their self-esteem making them feel confident to share their opinions as well as to create healthy social relationships.

One of the first communities a child will become part of will be the school. Educational institutions should train future citizens to become part of the democratic society in an active way. Consequently, it would make sense to say that schools should work as 
a utopian democracy would. The democratic school in Spain gives children a voice to be part of the decision-making process. In every meeting they vote on proposals that may be shared with other children, parents or teachers, participating as equals in the little democracy that they have built. Children feel they belong to a community that respects and supports them as well as giving them equal status with the adults together deciding about matters that concern them directly, in particular, their education. These children know the power they have as citizens, they know how to analyse proposals before voting and thinking in a critical way, making their own decisions. They are living in a democracy from when they start school, thus it is hoped they would be committed to democracy and standing up for their rights. This is an important aspect for Spanish society since we still are a young democracy.

Finally, this research compares the Scottish and Spanish Educational System [24] since there are schools from both countries participating in this study. The systems are very different, the first is more child-centered and allows families to choose the way to educate their children, while the second one is based on content and does not allow its citizens to choose what teaching and learning methods they want for their children. I hope this research will demonstrate the viability of a childcentered educational system, less worried about content and more focused on developing skills.

Democratic and alternative pedagogies can give children a personalized education, focused on their motivations and interests, based on their own research as a way to let them create their own knowledge and personal and emotional development. Namely, "integral" education [25] aimed at selfsufficiency.

\section{References}

[1] Europa Press (2013, 11 Abril). España se sitúa a la cabeza de la UE en fracaso escolar con un $25 \%$ en 2012 , según Eurostat [europapress.es] http://www.europapress.es /sociedad/educacion/noticia-espana-situa-cabeza-uefracaso-escolar-25-2012-eurostat-20130411140128.html

[2] El Mundo (2013, 24 Abril). Los niños españoles, los últimos del mundo en reconocer el acoso escolar. De: http://www.elmundo.es/elmundo/2013/04/24/espana/13668 11243.html

[3] García, E. (2014, 11 de Abril). España lidera el abandono escolar temprano con su mejor dato [elpais.com] http://sociedad.elpais.com/sociedad/2014/04/11/actualidad/ 1397211917_985641.html

[4] Molero, A. (1987) El modelo de maestro en el pensamiento de la Institución Libre de Enseñanza. Revista interuniversitaria de Formación del Profesorado, 7-22.
[5] Montessori, M. (1928) Ideas generales sobre el método: Manual Práctico. Madrid: CEPE S.L.

[6] Montessori, M. (1986) La mente absorbente del niño. México: Editorial Diana.

[7] Soëtard, M. (1994). Johan Heinrich Pestalozzi. Perspectivas: Revista Trimestral de Educación Comparada, 24, 299-313.

[8] Neill, A.S. (1994). Hijos en libertad. Barcelona: Editorial Gedisa.

[9] Neill, A.S. (1963) Summerhill, Un punto de vista radical sobre la educación de los niños. México: Fondo de Cultura Económica.

[10] Rosseau (2000) Emilio, o de la Educación. Madrid: Elaleph.com

[11] Ferrer, A. (2010) Rosseau: música y lenguaje. España: PUV.

[12] Cambridge Dictionary, (March, 2016) http://dictionary.cambridge.org/

[13] Zimmerman, B. J., Kitsantas, A., Campillo, M. (2005). Evaluación de la eficiencia autorregulatoria : Una perspectiva social cognitiva. Revista Evaluar, 5, 1-12

[14] Zimmerman, B. J., \& Schunk, D. H. (2001). Selfregulated learning and academic achievement: Theoretical perspectives. Mahwah, NJ: Lawrence Erlbaum.

[15] García, A (2013). Revisión y análisis de la metodología de incentivación y autorregulación en sistemas e-Learning en las Universidades Españolas (Trabajo de Fin de Grado). Universidad de Santiago de Compostela: Santiago de Compostela.

[16] Gonzalez, M. C. \& Torrano, F. (2004). El aprendizaje autorregulado: presente y futuro de la investigación. Revista Electrónica de Investigación Psicoeducativa, 2 (1), 1-34. http://www.investigacion-sicopedagogica.org/revista/ articulos/3/espannol/Art_3_27.pdf

[17] Peñalosa, E., Landa, P. \& Vega, C. Z. (2006). Aprendizaje Autorregulado: Una Revisión Conceptual. Revista Electrónica de Psicología de Iztacala. http://www.iztacala.unam.mx/carreras/psicologia/psiclin/v ol9num2/vol9n2art1.pdf

[18] Platon (2000). Obras Selectas. Madrid: Edimat Ediciones.

[19] Tolstoi, L. (1978) La escuela de Yásnaia Poliana. Barcelona: El Barquero.

[20] Lloyd, G. (2008) Aristóteles. Buenos Aires: Prometeo Libros.

[21] Filloux, J.C. (2008). Epistemología, ética y ciencias de la educación. Córdoba, Argentina: Editorial Brujas. 
[22] Ordoñez, M. (2008) La Mayéutica de Sócrates en la Formación Humana. Planeación y Evaluación Educativa. 43, 3-10.

[23] Moreira, M.A. (1997). Aprendizaje significativo: Un concepto subyacente. En M.A. Moreira, C. Caballero Sahelices y M.L. Rodríguez Palmero, Eds. Actas del II Encuentro Internacional sobre Aprendizaje Significativo. Servicio de Publicaciones. Universidad de Burgos,19-44.

[24] Ley Orgánica de Mejora de la Calidad Educativa (2014). En Boletín Oficial del Estado $n^{\circ} 52$. Gobierno de España.

[25] Murray, T (2009) What is the integral education? From progressive pedagogy to integral pedagogy. Integral Review, 5(1). http://www.perspegrity.com/papers/

ProgressiveToIntegralEd-Murray.pdf

[25] Pramling Samuelsson, I. \& Asplund Carlsson, M. (2008) The playing learning child: Towards a pedagogy of early childhood. Scandinavian Journal of Education Research, 52 (6), 623-641.

[26] Cohen, L., Manion, L. \& Morison, K. (2000). Research Methods in Education. London: Routledge Falmer

[27] Artola, T., Ancillo, I., Mosteiro, P. y Barraca, J. (2004) Prueba de Imaginación Creativa. Madrid: TEA.

[28] Beltrán J.A., Pérez L.F. y Ortega M.I. (2006) Cuestionario de Estrategias de Aprendizaje. Madrid: TEA.

[29] Gismero, E. (2002) Escala de Habilidades Sociales. Madrid: TEA.

[30] Mujis, D. (2011) Doing Quantitative Research in Education with SPSS. SAGE publications Ldt.: London.

[31] Etxeberria, J. \& Tejedor, J. (2009). Metodología de la investigación educativa. Editorial La Muralla: Madrid. 